\title{
Why do poxviruses still matter?
}

\author{
Zhilong Yang ${ }^{1,2^{*}}$, Mark Gray ${ }^{2}$ and Lake Winter ${ }^{2}$
}

\begin{abstract}
Poxviruses comprise many members that infect both vertebrate and invertebrate animals, including humans. Despite the eradication of the historically notorious smallpox, poxviruses remain significant public health concerns and serious endemic diseases. This short review briefly summarizes the present, historical, and future threats posed by poxviruses to public health, wildlife and domestic animals, the role poxviruses have played in shaping modern medicine and biomedical sciences, the insight poxviruses have provided into complex life processes, and the utility of poxviruses in biotechniques and in fighting other infectious diseases and cancers. It is anticipated that readers will appreciate the great merit and need for continued strong support of poxvirus research; research which benefits not only the expansion of fundamental biological knowledge but also the battle against diverse diseases.
\end{abstract}

Keywords: Poxvirus, Vaccinia virus, Virology, Smallpox, Vaccine vector, Oncolytic therapy, Biodefense, Public health, Animal health

\section{Background}

The poxvirus family is a large family of double-stranded DNA viruses designated Poxviridae. Based on the International Committee on Taxonomy of Viruses (ICTV) Taxonomy 2019 release [1], The Poxviridae comprises two subfamilies: Chordopoxvirinae (18 genera, 52 species) and Entomopoxvarinae (4 genera, 30 species). Poxviruses infect a range of animals including insects, birds, reptiles, marsupials, and mammals [2,3], and cause disease in many, including humans. In this review, we will briefly discuss the historical significance and research endeavors pertaining to poxviruses. We will then focus on why it is critical that we expand our understanding of these viruses.

\section{Poxviruses have historical, current, and future significance to public health}

Smallpox, caused by variola virus of the orthopoxvirus genera, is one of the most, if not the most, deadly and dreaded diseases in human history. While the origin

\footnotetext{
*Correspondence: zyang@cvm.tamu.edu

${ }^{1}$ Department of Veterinary Pathobiology, College of Veterinary Medicine \& Biomedical Sciences, Texas A\&M University, College Station, TX, USA

Full list of author information is available at the end of the article
}

of smallpox is unknown, it is believed that variola virus evolved from a rodent poxvirus [4]. While the lesions found on the mummy of Egyptian Pharaoh Ramesses V (died $1145 \mathrm{BC}$ ) suggest that smallpox existed over 3000 years ago $[5,6]$, the earliest written documentation of smallpox-like symptoms were from Ge Hong's (283-343, Eastern Jin Dynasty, China) book, Zhouhou Beiji Fan, or, Handbook of Prescriptions for Emergency. Smallpox has likely caused more human deaths than all other infectious diseases combined. According to an estimation by Crosby et al., 10-15 million people had been infected with smallpox in the year of 1967 [7]. With a mortality rate of $30-40 \%$, smallpox killed approximately 300 million people in the twentieth century alone [8]. Considering smallpox was eradicated in 1980, this estimation suggests approximately 5 million smallpox deaths per year during the endemic phase in the early years of the twentieth century. Notably, a negative correlation between human life expectancy and smallpox outbreaks was observed in Sweden between year 1774 and 1843 (Fig. 1, data from https://ourworldindata.org/smallpox) [9], when the date are available. This historic mortality has resulted in Smallpox outbreaks reshaping the history of many countries. For example, Emperor Kangxi (1654-1722), who ruled for over 60 years during the Qing 


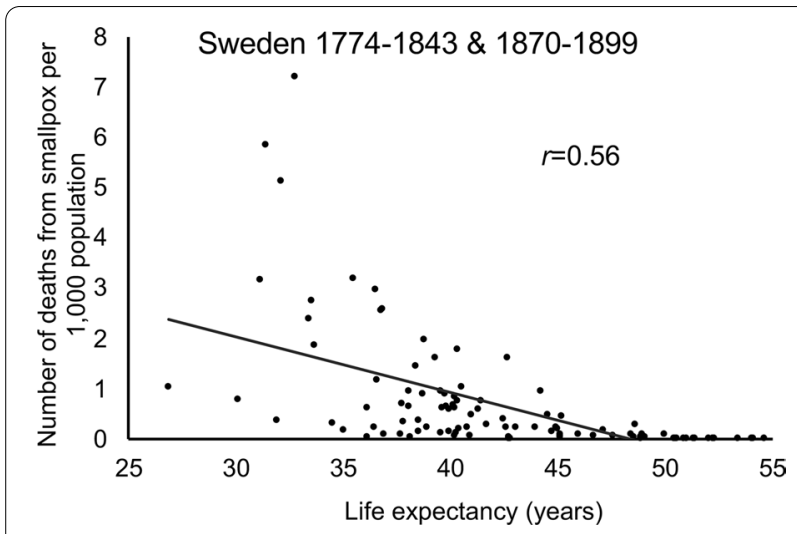

Fig. 1 Correlation coefficiency of life expectancy and number of deaths from smallpox per 1000 population from 1774 to 1899 in Sweden. Shown data points are for years available. Data was extracted from https://ourworldindata.org/smallpox

Dynasty, substantially influenced Chinese history. After he suffered from smallpox and survived, his immunity is believed to have aided in him becoming emperor [10].

While the World Health Organization (WHO) declared smallpox eradicated in 1980 following a world-wide vaccination campaign [11], concerns persist that smallpox may re-emerge accidently from forgotten stocks of the virus, from de novo synthesis, or from melting permafrost due to global warming $[12,13]$. This is especially worrisome because of the low worldwide vaccination rate against smallpox since 1980, reducing rates of smallpox immunity in the population. The US military considers the risk of weaponized smallpox sufficient to justify the continued vaccination of all its military personal against the disease [14]. While smallpox had caused countless human lives historically and they continue to pose threats to public health, only recently did the U.S. FDA approved TPOXX as the first specific smallpox drug [15]. TPOXX targets a major viral protein that is important for morphogenesis (i.e. F13 in vaccinia virus) [16]. Cidofovir has off-label use for poxvirus infection and was originally approved for AIDS-related retinal cytomegalovirus infection [17-19]. Drug-resistance and side effects are still the concerns [20], promoting the necessity to search for new drugs. In fact, the U.S. Biomedical Advanced Research and Development Authority of the federal HHS Office of the Assistant Secretary for Preparedness and Response (BARDA) is actively seeking a second smallpox drug for clinical development, according to a recommendation from the Institute of Medicine od the U.S. [21, 22].

Humans are the exclusive host of variola virus. Another poxvirus, molluscum contagiosum virus, also exclusively infects humans. Molluscum contagiosum accounts for 1 in 500 outpatient visits in the US and is particularly common in young people [23]. The virus causes self-limiting benign tumors in healthy people but can cause serious complications in immune-compromised individuals [23]. Besides these two human-specific poxviruses, many animal poxviruses can cause severe diseases in humans, and some others may potentially be the pathogens for diseases with unidentified causes. An ectromelia virus, erythromelalgia-associated poxvirus, or ERPV, was isolated from patients among school-age children in rural China. The disease is characterized by pharyngitis followed by burning pain and inflammation in the extremities, with seasonal outbreaks occurring every few years in spring or winter [24-26]. While whether ERPV is the cause of the epidemic erythromelalgia is still unclear and needs further investigation, some other poxviruses clearly cause human infections. For example, ORF virus causes sore mouth disease in goats and sheep, but can also infect humans. Cowpox virus can elicit serious illnesses in human hosts. A novel orthopoxvirus recently caused infections in humans in the state of Alaska and is believed to have been transmitted by animals [27, 28]. Monkeypox is endemic in Africa and has a $10 \%$ death rate among the humans it infects [2]. A study published in 2010 showed that monkeypox virus cases have increased over 20-fold in the Democratic Republic of Congo (DRC) during the 30 years following the termination of the smallpox vaccination campaign, as smallpox vaccine can protect humans from monkeypox infection. Individuals vaccinated against smallpox were at a 5.2-fold lower risk of contracting monkeypox compared to unvaccinated individuals [29]. New geographic areas reporting monkeypox cases have increased during recent years and now include the Central African Republic, DRC, Liberia, Nigeria, and Sierra Leone. In DRC, more than 1,000 suspected cases have been reported each year since 2005 [30]. According to the WHO, a total of 4,594 suspected cases of monkeypox were reported in the DRC from 1 January through 13 September 2020 (https://www.who. int/csr/don/01-october-2020-monkeypox-drc/en/). The numbers are likely underestimated due to a lack of reliable surveillance systems. Further spread of monkeypox is a real concern. In the last few years, several outbreaks of monkeypox have occurred in Central and Western Africa, and travel-related monkeypox cases have been reported in the United Kingdom, Israel, and Singapore [30-34]. An outbreak occurred in the USA in 2003 that was eventually traced to animals imported from Africa [35].

Among the numerous poxviruses that can infect animals, many have significant impacts on economically important livestock and ecologically endangered wildlife. Capripoxviruses cause lumpy skin disease (LSD) in cattle, 
sheep (sheeppox), and goats (goatpox), and can cause significant economic losses in commercial herds of these animals. Recent outbreaks of capripoxviruses in Asia indicate the expansion of the viruses into new regions in addition to Africa and the Middle East [36]. With increasing global trade, it would not be surprising to see these viruses continue to expand their geographic range. In addition to mammals, avipoxviruses impact hundreds of domestic and wild bird species, including chickens, turkeys, penguins, and songbirds, risking economic loss and endangering wildlife [37, 38]. Other examples of poxvirus diseases include swinepox, salmon gillpox, and crocodile pox [2].

\section{Poxviruses have shaped modern medicine and biomedical science}

The battle against smallpox made important contributions to the development of modern medicine and the biomedical sciences. Edward Jenner, the famous English physician and scientist, carried out pioneering work to combat infectious disease through vaccination, applying a scientific approach to preventing smallpox prior to the widespread acceptance of germ theory. In 1980, one hundred and eight-two years after Jenner published his work An inquiry into the causes and effects of the variolae vaccinae in 1798, the WHO declared the eradication of smallpox through a global vaccination campaign [11]. As of 2021, smallpox is the first and only human disease to have been eradicated by deliberate vaccination. The great success of this evidence-based scientific approach to eradicate a specific disease greatly increased people's acceptance of modern biomedical practices and many believe that smallpox eradication remains the most important achievement of modern medicine.

Jenner's work on smallpox vaccination had profound influence on the development of many core branches of today's biomedical sciences. The impact of his work on modern vaccinology is apparent, as there are numerous human vaccines available today, protecting us from over two dozen infectious diseases. There are also many veterinary vaccines now in use. It is particularly remarkable that multiple severe acute respiratory syndrome coronavirus 2 (SARS-CoV-2) vaccines have been successfully developed and approved for use, all within one year of the discovery of the pathogen responsible for the COVID-19 pandemic. Although Jenner's work preceded the germ theory of infectious disease and immunity theory after infection, his successful smallpox vaccination work provided the foundation for these groundbreaking theories to gain acceptance. As a result, Jenner is now widely regarded as the founding father of immunology [39].

As the vaccine used to eradicate smallpox and the prototypic member of poxviruses, vaccinia virus has become the most extensively studied virus in the Poxviridae family, contributing many critical concepts to the development of modern virology and molecular biology. For example, the publication, Studies on the Cultivation of the Virus of Vaccinia, by Steinhardt and Lambert in 1913 documented the first animal virus successfully grown in tissue culture [40]. The production of viruses in tissue culture has proven fundamental to the research underpinning virtually all modern virology. Vaccinia virus went on to be used to elucidate the virion containing transcription machinery and the 5' cap structure of eukaryotic mRNAs to name only two examples of the paradigm shifts in the field of virology (and more broadly in biology) that would not have been possible before [41-44].

\section{Poxviruses provide ample opportunities to understand complex life processes}

Of the dozens of poxviruses, each has a DNA genome encoding hundreds of genes that support a complex replication cycle [3]. Many of the poxviruses' encoded enzymes are utilized as tools for molecular biology and biotechniques. A number of commercialized biotechnology products have been successfully developed based on enzymes identified from vaccinia virus, exemplified by the vaccinia capping system for in vitro synthesized RNA and TOPO cloning which is based on vaccinia DNA topoisomerase $[45,46]$. It will not be surprising to see more poxvirus-based biotechnology products in the future. In addition, although poxviruses are "old" viruses, many mechanisms of their replication cycle are still poorly understood, partially because of their complex virion and life cycle. For example, vaccinia virus needs a complex comprising 11 proteins for cell fusion and entry [47]; the most complex fusion-entry system among known mammalian viruses. The mechanism of entry is still largely unknown. Many other aspects of poxvirus virion assembly, membrane morphogenesis, and egress are also still poorly understood. Therefore, poxviruses provide phenomenal scientific opportunities for investigators in the field of virology.

Although poxviruses encode hundreds of genes, similar to other viruses, they still rely on host cells to complete their replication cycle and have complex interactions with their hosts. Eukaryotic cells, including mammalian cells, have a well-developed innate immune system to detect, respond to, and limit viral pathogens. It is estimated that more than one third of the over 200 vaccinia virus-encoded genes are dedicated to modulating innate immune response as a strategy to evade host antiviral immunity. Vaccinia's viral proteins can counteract almost all known innate immune mechanisms. An outstanding review by Smith et. al. summarized these vaccinia virus immunomodulatory proteins nicely [48]. More vaccinia 
virus innate immunomodulatory proteins continue to be described and characterized. For example, B2 and F17 use distinct mechanisms to evade the cGAS-STING DNA sensing pathway $[49,50]$. Yet, the functions and mechanisms of action of many of these poxvirus immunomodulators are unknown. Many of the remaining poxvirus non-immunomodulators also interact with cellular processes to facilitate virus entry, DNA replication, gene expression, viral envelop membrane morphogenesis, assembly, egress, and spreading. Research on these poxvirus gene functions will provide molecular tools to decipher aspects of cellular processes, in addition to understanding viral replication strategies. Work in the author's laboratory has recently focused on vaccinia virus factors that interact with host cell protein synthesis and metabolism machinery [51-57], with the rational that the study of virus interactions with these host housekeeping functions is critical to elucidate the poxvirus replication strategy and the associated fundamental cellular processes.

\section{Employing poxviruses to fight other diseases}

Poxviruses are broadly used as tools to fight many other diseases. They are being developed as vaccine vectors for other infectious diseases, oncolytic therapeutics for many cancers, gene delivery vehicles, and protein expression systems in mammalian cells. Several inherent biological features of poxviruses render them extremely effective as vaccine and gene-delivery vectors and as oncolytic agents. First, poxviruses have large genomes, which allow large foreign DNA fragment (over $25 \mathrm{~kb}$ ), containing multiple genes, to be inserted in the viral genome for genetic engineering [58-60]. Second, the entire poxvirus replication cycle is in the cytoplasm and does not enter the nucleus [3], which provides poxviruses an advantage as vaccine vectors and oncolytic agents since the viral DNA is unlikely to be integrated into the host genome. Third, the poxvirus genes are expressed as a cascade with early, intermediate, and late classes and a broad range of expression levels [3, 61-63], which provides ample opportunity to modulate the expression timing and level of foreign genes. Fourth, plenty of data has been accumulated during the world-wide smallpox vaccination campaign, which provides an excellent safety baseline and is useful for further improving the safety profile. Fifth, poxvirus-vectored vaccines have the capability to induce both humoral and cellular immune responses to foreign antigens they carry [64]. Sixth, there are many poxviruses, including replicating and non-replicating ones in humans and other animals, allowing researchers to choose the most applicable. Seventh, poxviruses are stable, grow very fast, and can be produced at high titers for large scale manufacture. Lastly, when used in oncolytic therapy, poxvirus infection can stimulate anti-tumor immunity [65], which is critical to removing cancer cells.

Poxviruses began to be employed as vaccine vectors almost four decades ago in the early 1980s when several groups pioneered their use to express foreign antigens [66-72]. Since then, a number of veterinary vaccines based on different poxviruses have been commercially licensed, including the rabies vaccine. Rabies virus infection of humans is deadly, and most transmissions are through bites from infected animals. Recombinant vaccinia virus expressing rabies virus glycoprotein $G$ has been successfully used to eliminate rabies from wildlife in some Western European countries [73-79]. In addition, ALVAC is a canarypox virus-based vector system, which has been used to develop several veterinary vaccines such as canine distemper virus, rabies virus, and equine influenza virus $[80,81]$. Another veterinary vaccine, Trovac AI $\mathrm{H} 5$, is a fowlpox virus-based avian influenza virus vaccine expressing the avian influenza viral $\mathrm{H} 5$ antigen, which has been used in the United States and Central America [82]. Many human vaccines based on poxviruses, targeting various other infectious diseases, including HIV/ AIDS, influenza, and Tuberculosis, are at different clinical or preclinical stages, comprehensively summarized by Sanchez-Sampedro et al. [83]. Many more poxvirusbased vaccines are under investigation. Recent efforts have focused on using Modified Vaccina virus Ankara to develop vaccines against SARS-CoV-2. These have shown promising effects in mice and macaques [84-87]. With further research, it is expected that poxvirus vector-based vaccines will be licensed for humans, which requires substantially increasing the investments and efforts to understand the fundamental aspects of poxvirus replication, as well as collaboration among poxvirologists, immunologists, clinicians, and veterinarians.

Oncolytic virotherapy is a targeted cancer therapy using viruses to infect and destroy cancer cells. While the idea to use viruses to treat cancers has been of interest to medical doctors for over a century, only in the past few decades has it become a highly promising and rapidly developing area. A growing number of patients benefit from this oncolytic therapy [88]. A herpesvirusbased oncolytic melanoma treatment, T-VEC, which met the US Food and Drug Administration (FDA) requirements in 2015, was the first treatment of this kind to gain approval [89]. There are a number of viruses with diverse characteristics in development to treat many kinds of cancers and poxviruses are among the most promising candidates for oncolytic actions. While several members of poxviruses from different genera (Orthopoxvirus, Leporipoxvirus, and Yatapoxvirus) have been the target of development, most research in the past decade has been focused on vaccinia virus (Orthopoxvirus) and myxoma 


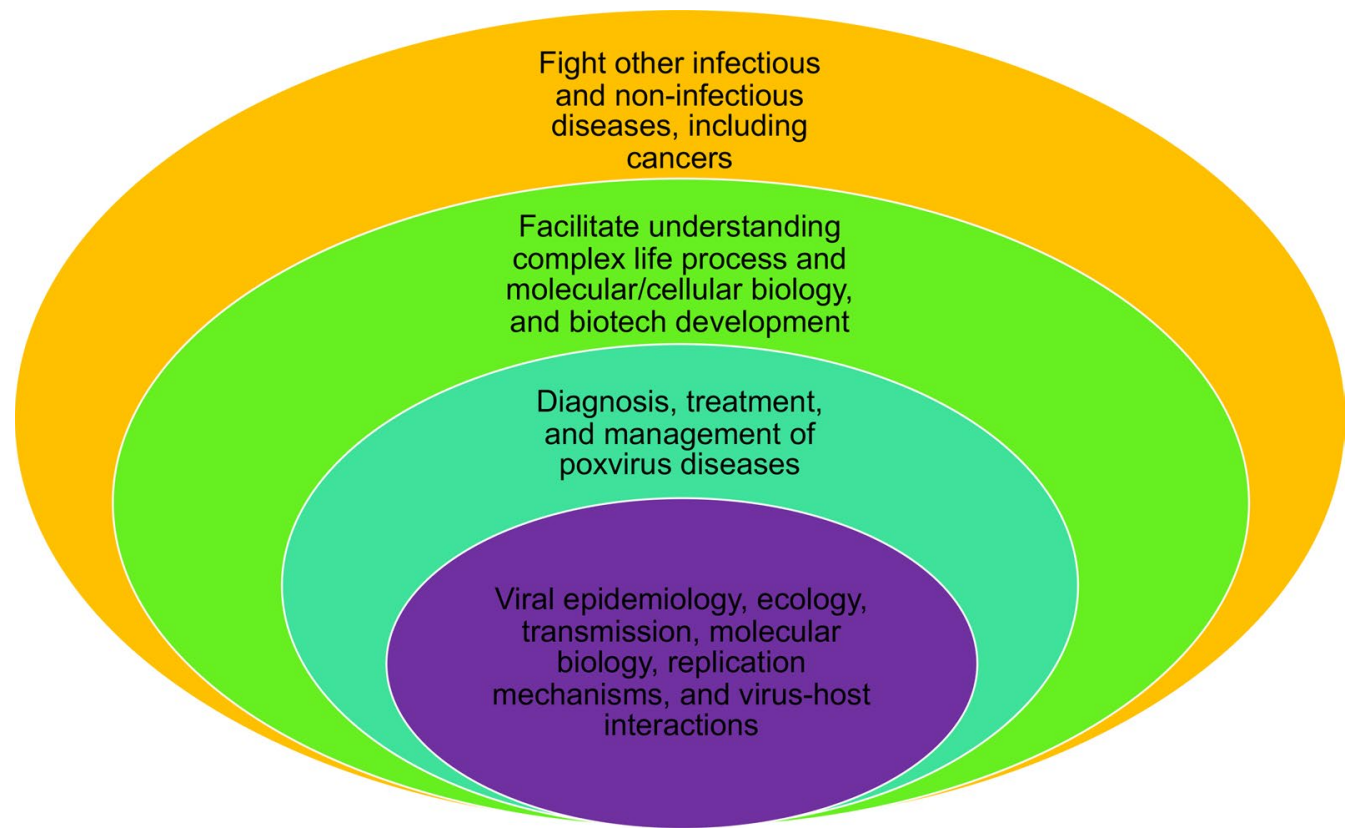

Fig. 2 A perspective on poxvirus research

virus (Leporipoxvirus) [90-95]. JX-594 was developed based on a modified vaccinia Copenhagen strain with deletion of viral thymidine kinase gene and insertion of granulocyte monocyte colony-stimulating factor (GMCSF), which aimed to improve the ability of the virus to target and lyse cancer cells with specificity and stimulate anti-tumor immune responses. It was the first vaccinia virus-based oncolytic therapy that was tested in clinical trials starting with melanoma patients and was later engineered to combat other types of cancers [96-103]. More vaccinia virus strains have been developed and are in various stages of clinical or pre-clinical trials to treat hepatocellular carcinoma, pediatric solid tumors, lung cancer, etc. [104]. Interestingly, a non-replicating, inactivated modified vaccinia Ankara (MVA) has also been shown to have oncolytic potential [65], which would enhance the safety profiling of vaccinia virus-based oncolytic therapy. Another poxvirus with great potential in oncolytic research is myxoma virus [93, 105]. Myxoma viruses' natural hosts are rabbits and so, advantageously, myxoma virus is non-replicating in normal human cells. However, studies have found that this virus can infect and kill non-rabbit cancer cells, including human cancer cells. This implies a robust safety profile for myxoma virus as it does not seem to do any harm, even to immunocompromised mice [93]. A recent review by Torres-Domínguez et al. comprehensively describes the progress in this field [104]. More development of poxviruses to fight different cancers in humans and animals is anticipated. Another critical aspect is to understand the functions of poxvirus genes in modulating the tumor microenvironment and anti-tumor immunity, which will allow genetic engineering of poxviruses to enhance their oncolytic specificity, potency, and safety profile.

\section{Conclusion remarks and perspectives}

The poxvirus family includes many members that are pathogenic to humans and animals and pose significant risk to public health and economic activity. Understanding this large family of viruses, including their epidemiology, transmission, ecology, molecular biology, replication mechanisms, and strategies to take over the host cells, is the most critical task for developing the means to diagnose, treat, and manage these viruses; along with preventing future outbreaks. It is of note that almost all of these aspects of poxviruses are under-studied, and many questions remain unanswered. Poxviruses also possess tremendous scientific value for understanding life processes and cellular biology, thanks to their large genomes, complex virions, and life cycle. The utility of poxviruses in fighting other infectious diseases and cancers also has great potential. Improved understanding of this family of viruses will provide the foundation for genetically engineering them as better vaccine- and gene-delivery vectors and oncolytic agents. Figure 2 illustrates the aspects the author believes are critical in understating poxviruses and their utilities.

\section{Acknowledgements}

We apologize that we could only cite a limited number of references in this paper. 


\section{Authors' contributions}

ZY drafted the initial manuscript. ZY, MG, and LW edited the manuscript. All authors read and approved the final manuscript.

\section{Funding}

ZY is supported by a grant from the National Institutes of Health (Grant\# R01 Al143709, https://www.nih.gov). Lake Winter is supported by Kansas-INBRE Undergraduate Student Scholar Award (P20 GM103418) and Johnson Cancer Research Award. The funders had no roles in preparation of the manuscript.

\section{Availability of data and materials}

Not applicable.

\section{Declarations}

\section{Ethics approval and consent to participate}

Not applicable.

\section{Consent for publication}

Not applicable.

\section{Competing Interest}

The authors declare that they have no competing interests.

\section{Author details}

${ }^{1}$ Department of Veterinary Pathobiology, College of Veterinary Medicine \& Biomedical Sciences, Texas A\&M University, College Station, TX, USA. ${ }^{2}$ Division of Biology, Kansas State University, Manhattan, KS, USA.

Received: 1 April 2021 Accepted: 11 May 2021

Published online: 22 May 2021

\section{References}

1. (ICTV) ICoToV. EC 51, Berlin, Germany, July 2019; Email ratification March 2020 (MSL \#35). 2019.

2. Damon IK. Poxviruses. 6th ed. In: Knipe DM, Howley PM, editors. Fields Virology, vol. 2. Lippincott; 2013. p. 2160-84.

3. Moss B. Poxviridae: the viruses and their replication. In: Knipe DM, Howley PM, editors. Fields virology, vol. 2. Lippincott; 2013. p. 2129-59.

4. Esposito JJ, Sammons SA, Frace AM, Osborne JD, Olsen-Rasmussen M, Zhang $M$, et al. Genome sequence diversity and clues to the evolution of variola (smallpox) virus. Science. 2006;313(5788):807-12.

5. Hopkins, DR. (1980)! Ramses V: earliest know victim?. World Health, p.22-6. https://apps.who.int/iris/handle/10665/202495

6. Fenner FHD, Arita I, Jezek Z, Ladnyi ID. Smallpox and its eradication. Geneva: World Health Organization; 1988.

7. Crosby AW (1993). Smallpox. In K.F. Kiple, (pp 1008-14). Cambridge: Cambridge University Press.

8. Henderson DA. The eradication of smallpox-an overview of the past, present, and future. Vaccine. 2011;29(Suppl 4):D7-9.

9. Edwardes EJ. A concise history of small-pox and vaccination in Europe. London: H.K. Lewis; 1902.

10. Chang CF. Disease and its impact on politics, diplomacy, and the military: the case of smallpox and the Manchus (1613-1795). J Hist Med Allied Sci. 2002:57(2):177-97.

11. Fenner F. The global eradication of smallpox. Med J Aust. 1980;1(10):455-65.

12. Noyce RS, Lederman S, Evans DH. Construction of an infectious horsepox virus vaccine from chemically synthesized DNA fragments. PLoS ONE. 2018;13(1):e0188453.

13. McCarthy M. Smallpox samples are found in FDA storage room in Maryland. BMJ. 2014;349:g4545.

14. Institute of Medicine (US) Committee on a Strategy for Minimizing the Impact of Naturally Occurring Infectious Diseases of Military Importance: Vaccine Issues in the U.S. Military. Protecting our forces: improving vaccine acquisition and availability in the U.S. military. Lemon SM, Thaul S, Fisseha S, Maonaigh HC, editors. Washington, DC: The National Academies Press; 2002. 158p.
15. Hoy SM. Tecovirimat: first global approval. Drugs. 2018;78(13):1377-82.

16. Duraffour S, Vigne S, Vermeire K, Garcel A, Vanstreels E, Daelemans D, et al. Specific targeting of the F13L protein by ST-246 affects orthopoxvirus production differently. Antivir Ther. 2008;13(8):977-90.

17. Smee DF, Sidwell RW. A review of compounds exhibiting anti-orthopoxvirus activity in animal models. Antiviral Res. 2003;57(1-2):41-52.

18. Jesus DM, Costa LT, Goncalves DL, Achete CA, Attias M, Moussatche $\mathrm{N}$, et al. Cidofovir inhibits genome encapsidation and affects morphogenesis during the replication of vaccinia virus. J Virol. 2009;83(22):11477-90.

19. Andrei G, Snoeck R. Cidofovir activity against poxvirus infections. Viruses. 2010;2(12):2803-30.

20. Robbins SJ, Jackson RJ, Fenner F, Beaton S, Medveczky J, Ramshaw IA, et al. The efficacy of cidofovir treatment of mice infected with ectromelia (mousepox) virus encoding interleukin-4. Antiviral Res. 2005:66(1):1-7.

21. Editorial. The spectre of smallpox lingers. Nature 2018;560(7718):281.

22. Institution of Medicine. Live Variola Virus: Consideration for Continuing Research (2009). 2009

23. Reynolds MG, Holman RC, Yorita Christensen KL, Cheek JE, Damon IK. The incidence of molluscum contagiosum among American Indians and Alaska Natives. PLoS ONE. 2009;4(4):e5255.

24. Mendez-Rios JD, Martens CA, Bruno DP, Porcella SF, Zheng ZM, Moss B. Genome sequence of erythromelalgia-related poxvirus identifies it as an ectromelia virus strain. PLoS ONE. 2012;7(4):e34604.

25. Zheng ZM, Specter S, Zhang JH, Friedman H, Zhu WP. Further characterization of the biological and pathogenic properties of erythromelalgia-related poxviruses. J Gen Virol. 1992;73(Pt 8):2011-19.

26. Zheng ZM, Zhang JH, Hu JM, Liu SF, Zhu WP. Poxviruses isolated from epidemic erythromelalgia in China. Lancet. 1988;1(8580):296.

27. Department of Health and Social Services. Second case of Novel orthopoxvirus infection in a Fairbanks-area resident. State of Alaska Epidemiology Bulletin. 2020(11).

28. Springer YP, Hsu CH, Werle ZR, Olson LE, Cooper MP, Castrodale L, et al. Novel orthopoxvirus infection in an Alaska resident. Clin Infect Dis. 2017;64(12):1737-41.

29. Rimoin AW, Mulembakani PM, Johnston SC, Lloyd Smith JO, Kisalu NK Kinkela TL, et al. Major increase in human monkeypox incidence 30 years after smallpox vaccination campaigns cease in the Democratic Republic of Congo. Proc Natl Acad Sci USA. 2010:107(37):16262-7.

30. Durski KN, McCollum AM, Nakazawa Y, Petersen BW, Reynolds MG, Briand S, et al. Emergence of Monkeypox-West and Central Africa, 1970-2017. MMWR Morb Mortal Wkly Rep. 2018;67(10):306-10.

31. Vaughan A, Aarons E, Astbury J, Balasegaram S, Beadsworth M, Beck $C R$, et al. Two cases of monkeypox imported to the United Kingdom, September 2018. Euro Surveill. 2018;23(38):1800509.

32. Erez N, Achdout $H$, Milrot E, Schwartz $Y$, Wiener-Well $Y$, Paran N, et al. Diagnosis of imported Monkeypox, Israel, 2018. Emerg Infect Dis. 2019:25(5):980-3.

33. Yong SEF, Ng OT, Ho ZJM, MakTM, Marimuthu K, Vasoo S, et al. Imported Monkeypox, Singapore. Emerg Infect Dis. 2020;26(8):1826-30.

34. Ng OT, Lee V, Marimuthu K, Vasoo S, Chan G, Lin RTP, et al. A case of imported Monkeypox in Singapore. Lancet Infect Dis. 2019;19(11):1166.

35. Centers for Disease C, Prevention. Update: multistate outbreak of monkeypox--Illinois, Indiana, Kansas, Missouri, Ohio, and Wisconsin, 2003. MMWR Morb Mortal Wkly Rep 2003;52(27):642-6.

36. Tuppurainen ESM, Venter EH, Shisler JL, Gari G, Mekonnen GA, Juleff N, et al. Review: capripoxvirus diseases: current status and opportunities for control. Transbound Emerg Dis. 2017;64(3):729-45.

37. Weli SC, Tryland M. Avipoxviruses: infection biology and their use as vaccine vectors. Virol J. 2011;8:49.

38. Pello SJ, Olsen GH. Emerging and reemerging diseases of avian wildlife. Vet Clin North Am Exot Anim Pract. 2013;16(2):357-81.

39. History - Edward Jenner (1749-1823). BBC. 1 November 2006. https:// www.bbc.co.uk/history/historic_figures/jenner_edward.shtml

40. Steinhardt E, Israeli C, Lambert RA. Studies on the cultivation of the virus of vacciniat. J Infect Dis. 1913;13(2):294-300.

41. Moss B. 5' end labeling of RNA with capping and methylating enzymes. Gene Amplif Anal. 1981;2:253-66. 
42. Wei C, Moss B. 5'-Terminal capping of RNA by guanylyltransferase from HeLa cell nuclei. Proc Natl Acad Sci USA. 1977;74(9):3758-61.

43. Munyon W, Paoletti E, Grace JT Jr. RNA polymerase activity in purified infectious vaccinia virus. Proc Natl Acad Sci USA. 1967;58(6):2280-7.

44. Kates JR, McAuslan BR. Poxvirus DNA-dependent RNA polymerase. Proc Natl Acad Sci USA. 1967;58(1):134-41.

45. Shuman S. Catalytic activity of vaccinia mRNA capping enzyme subunits coexpressed in Escherichia coli. J Biol Chem. 1990;265(20):1 1960-6.

46. Geng $L$, Xin W, Huang DW, Feng G. A universal cloning vector using vaccinia topoisomerase I. Mol Biotechnol. 2006;33(1):23-8.

47. Moss B. Poxvirus cell entry: how many proteins does it take? Viruses. 2012;4(5):688-707.

48. Smith GL, Benfield CT, Maluquer de Motes C, Mazzon M, Ember SW, Ferguson BJ, et al. Vaccinia virus immune evasion: mechanisms, virulence and immunogenicity. J Gen Virol. 2013;94(Pt 11):2367-92.

49. Meade N, King M, Munger J, Walsh D. mTOR dysregulation by vaccinia virus F17 controls multiple processes with varying roles in infection. J Virol. 2019. https://doi.org/10.1128/JVI.00784-19.

50. Eaglesham JB, Pan Y, Kupper TS, Kranzusch PJ. Viral and metazoan poxins are CGAMP-specific nucleases that restrict CGAS-STING signalling. Nature. 2019;566(7743):259-63.

51. Pant A, Dsouza L, Cao S, Peng C, Yang Z. Viral growth factor- and STAT3 signaling-dependent elevation of the TCA cycle intermediate levels during vaccinia virus infection. PLoS Pathog. 2021;17(2):e1009303.

52. Pant A, Yang Z. Asparagine: an achilles heel of virus replication? ACS Infect Dis. 2020;6(9):2301-3.

53. Dhungel P, Cantu FM, Molina JA, Yang Z. Vaccinia virus as a master of host shutoff induction: targeting processes of the central dogma and beyond. Pathogens. 2020;9(5):400.

54. Pant A, Cao S, Yang Z. Asparagine is a critical limiting metabolite for vaccinia virus protein synthesis during glutamine deprivation. J Virol. 2019. https://doi.org/10.1128/JVI.01834-18.

55. Dhungel P, Cao S, Yang Z. The 5'-poly(A) leader of poxvirus mRNA confers a translational advantage that can be achieved in cells with impaired cap-dependent translation. PLoS Pathog. 2017;13(8):e1006602.

56. Dai A, Cao S, Dhungel P, Luan Y, Liu Y, Xie Z, et al. Ribosome profiling reveals translational upregulation of cellular oxidative phosphorylation mrnas during vaccinia virus-induced host shutoff. J Virol. 2017. https:// doi.org/10.1128/JVI.01858-16.

57. Cantu F, Cao S, Hernandez C, Dhungel P, Spradlin J, Yang Z. Poxvirusencoded decapping enzymes promote selective translation of viral mRNAs. PLoS Pathog. 2020;16(10):e1008926.

58. Perkus ME, Piccini A, Lipinskas BR, Paoletti E. Recombinant vaccinia virus: immunization against multiple pathogens. Science. 1985:229(4717):981-4.

59. Paoletti E, Perkus ME, Piccini A. Live recombinant vaccines using genetically engineered vaccinia virus. Antivir Res. 1985;5(Suppl1):301-7.

60. Smith GL, Moss B. Infectious poxvirus vectors have capacity for at least 25000 base pairs of foreign DNA. Gene. 1983;25(1):21-8.

61. Yang Z, Bruno DP, Martens CA, Porcella SF, Moss B. Simultaneous highresolution analysis of vaccinia virus and host cell transcriptomes by deep RNA sequencing. Proc Natl Acad Sci USA. 2010;107(25):11513-8.

62. Yang Z, Reynolds SE, Martens CA, Bruno DP, Porcella SF, Moss B. Expression profiling of the intermediate and late stages of poxvirus replication. J Virol. 2011;85(19):9899-908.

63. Yang Z, Maruri-Avidal L, Sisler J, Stuart CA, Moss B. Cascade regulation of vaccinia virus gene expression is modulated by multistage promoters. Virology. 2013;447(1-2):213-20.

64. Bennink JR, Yewdell JW, Smith GL, Moller C, Moss B. Recombinant vaccinia virus primes and stimulates influenza haemagglutinin-specific cytotoxic T cells. Nature. 1984;311(5986):578-9.

65. Dai P, Wang W, Yang N, Serna-Tamayo C, Ricca JM, Zamarin D, et al. Intratumoral delivery of inactivated modified vaccinia virus Ankara (iMVA) induces systemic antitumor immunity via STING and Batf3-dependent dendritic cells. Sci Immunol. 2017:2(11):eaa111713.

66. Moss B, Smith GL, Mackett M. Use of vaccinia virus as an infectious molecular cloning and expression vector. Gene Amplif Anal. 1983;3:201-13.
67. Mackett M, Smith GL, Moss B. Vaccinia virus: a selectable eukaryotic cloning and expression vector. Proc Natl Acad Sci USA. 1982;79(23):7415-9.

68. Paoletti E, Lipinskas BR, Samsonoff C, Mercer S, Panicali D. Construction of live vaccines using genetically engineered poxviruses: biological activity of vaccinia virus recombinants expressing the hepatitis $B$ virus surface antigen and the herpes simplex virus glycoprotein D. Proc Natl Acad Sci USA. 1984;81(1):193-7.

69. Panicali D, Davis SW, Weinberg RL, Paoletti E. Construction of live vaccines by using genetically engineered poxviruses: biological activity of recombinant vaccinia virus expressing influenza virus hemagglutinin. Proc Natl Acad Sci USA. 1983;80(17):5364-8.

70. Panicali D, Paoletti E. Construction of poxviruses as cloning vectors: insertion of the thymidine kinase gene from herpes simplex virus into the DNA of infectious vaccinia virus. Proc Natl Acad Sci USA. 1982;79(16):4927-31.

71. Smith GL, Mackett M, Moss B. Infectious vaccinia virus recombinants that express hepatitis B virus surface antigen. Nature. 1983;302(5908):490-5.

72. Moss B. Reflections on the early development of poxvirus vectors. Vaccine. 2013;31(39):4220-2.

73. Brochier B, Costy F, Pastoret PP. Elimination of fox rabies from Belgium using a recombinant vaccinia-rabies vaccine: an update. Vet Microbiol. 1995:46(13):269-79.

74. Wiktor TJ, MacFarlan RI, Reagan KJ, Dietzschold B, Curtis PJ, Wunner $\mathrm{WH}$, et al. Protection from rabies by a vaccinia virus recombinant containing the rabies virus glycoprotein gene 1984. Biotechnology. 1992;24:508-12.

75. Kieny MP, Lathe R, Drillien R, Spehner D, Skory S, Schmitt D, et al. Expression of rabies virus glycoprotein from a recombinant vaccinia virus. Nature. 1984;312(5990):163-6.

76. Brochier B, Kieny MP, Costy F, Coppens P, Bauduin B, Lecocq JP, et al. Large-scale eradication of rabies using recombinant vaccinia-rabies vaccine. Nature. 1991;354(6354):520-2.

77. Slate D, Rupprecht CE, Rooney JA, Donovan D, Lein DH, Chipman RB. Status of oral rabies vaccination in wild carnivores in the United States. Virus Res. 2005;111(1):68-76.

78. Rupprecht CE, Wiktor TJ, Johnston DH, Hamir AN, Dietzschold B, Wunner WH, et al. Oral immunization and protection of raccoons (Procyon lotor) with a vaccinia-rabies glycoprotein recombinant virus vaccine. Proc Natl Acad Sci USA. 1986;83(20):7947-50.

79. Wiktor TJ, Macfarlan RI, Reagan KJ, Dietzschold B, Curtis PJ, Wunner $W H$, et al. Protection from rabies by a vaccinia virus recombinant containing the rabies virus glycoprotein gene. Proc Natl Acad Sci USA. 1984;81(22):7194-8

80. Taylor J, Meignier B, Tartaglia J, Languet B, VanderHoeven J, Franchini $G$, et al. Biological and immunogenic properties of a canarypoxrabies recombinant, ALVAC-RG (VCP65) in non-avian species. Vaccine. 1995;13(6):539-49.

81. Minke JM, Audonnet JC, Fischer L. Equine viral vaccines: the past, present and future. Vet Res. 2004;35(4):425-43.

82. Bublot M, Pritchard N, Swayne DE, Selleck P, Karaca K, Suarez DL, et al. Development and use of fowlpox vectored vaccines for avian influenza. Ann N Y Acad Sci. 2006;1081:193-201.

83. Sanchez-Sampedro L, Perdiguero B, Mejias-Perez E, Garcia-Arriaza J, Di Pilato M, Esteban M. The evolution of poxvirus vaccines. Viruses. 2015;7(4):1726-803.

84. Chiuppesi F, Salazar MD, Contreras H, Nguyen VH, Martinez J, Park Y, et al. Development of a multi-antigenic SARS-CoV-2 vaccine candidate using a synthetic poxvirus platform. Nat Commun. 2020;11(1):6121.

85. Garcia-Arriaza J, Garaigorta U, Perez P, Lazaro-Frias A, Zamora C, Gastaminza P, et al. COVID-19 vaccine candidates based on modified vaccinia virus Ankara expressing the SARS-CoV-2 spike induce robust T- and B-cell immune responses and full efficacy in mice. JVirol. 2021. https:// doi.org/10.1128/JVI.02260-20.

86. Liu R, Americo JL, Cotter CA, Earl PL, Erez N, Peng C, et al. One or two injections of MVA-vectored vaccine shields hACE2 transgenic mice from SARS-CoV-2 upper and lower respiratory tract infection. Proc Natl Acad Sci USA. 2021;118(12):e2026785118. 
87. Routhu NK, Cheedarla N, Gangadhara S, Bollimpelli VS, Boddapati AK, Shiferaw A, et al. A modified vaccinia Ankara vector-based vaccine protects macaques from SARS-CoV-2 infection, immune pathology, and dysfunction in the lungs. Immunity. 2021;54(3):542-56 e9.

88. Donnelly O, Harrington $\mathrm{K}$, Melcher A, Pandha H. Live viruses to treat cancer. J R Soc Med. 2013;106(8):310-4.

89. Pol J, Kroemer G, Galluzzi L. First oncolytic virus approved for melanoma immunotherapy. Oncoimmunology. 2016;5(1):e1115641.

90. Timiryasova TM, Li J, Chen B, Chong D, Langridge WH, Gridley DS, et al. Antitumor effect of vaccinia virus in glioma model. Oncol Res. 1999;11(3):133-44.

91. Evgin L, Vaha-Koskela M, Rintoul J, Falls T, Le Boeuf F, Barrett JW, et al. Potent oncolytic activity of raccoonpox virus in the absence of natural pathogenicity. Mol Ther. 2010;18(5):896-902.

92. Ricordel M, Foloppe J, Pichon C, Sfrontato N, Antoine D, Tosch C, et al. Cowpox virus: a new and armed oncolytic poxvirus. Mol Ther Oncolytics. 2017;7:1-11.

93. Rahman MM, McFadden G. Oncolytic virotherapy with myxoma virus. J Clin Med. 2020;9(1):171.

94. Guo ZS, Lu B, Guo Z, Giehl E, Feist M, Dai E, et al. Vaccinia virus-mediated cancer immunotherapy: cancer vaccines and oncolytics. J Immunother Cancer. 2019;7(1):6.

95. Hu Y, Lee J, McCart JA, Xu H, Moss B, Alexander HR, et al. Yaba-like disease virus: an alternative replicating poxvirus vector for cancer gene therapy. J Virol. 2001;75(21):10300-8.

96. Breitbach CJ, Burke J, Jonker D, Stephenson J, Haas AR, Chow LQ, et al. Intravenous delivery of a multi-mechanistic cancer-targeted oncolytic poxvirus in humans. Nature. 2011;477(7362):99-102.

97. Liu TC, Hwang T, Park BH, Bell J, Kirn DH. The targeted oncolytic poxvirus JX-594 demonstrates antitumoral, antivascular, and antiHBV activities in patients with hepatocellular carcinoma. Mol Ther. 2008;16(9):1637-42

98. Kim JH, Oh JY, Park BH, Lee DE, Kim JS, Park HE, et al. Systemic armed oncolytic and immunologic therapy for cancer with JX-594, a targeted poxvirus expressing GM-CSF. Mol Ther. 2006;14(3):361-70.
99. Parato KA, Breitbach CJ, Le Boeuf F, Wang J, Storbeck C, Ilkow C, et al. The oncolytic poxvirus JX-594 selectively replicates in and destroys cancer cells driven by genetic pathways commonly activated in cancers. Mol Ther. 2012;20(4):749-58.

100. Heo J, Reid T, Ruo L, Breitbach CJ, Rose S, Bloomston M, et al. Randomized dose-finding clinical trial of oncolytic immunotherapeutic vaccinia JX-594 in liver cancer. Nat Med. 2013;19(3):329-36.

101. Park SH, Breitbach CJ, Lee J, Park JO, Lim HY, Kang WK, et al. Phase $1 \mathrm{~b}$ trial of biweekly intravenous Pexa-Vec (JX-594), an oncolytic and immunotherapeutic vaccinia virus in colorectal cancer. Mol Ther. 2015;23(9):1532-40.

102. Cripe TP, Ngo MC, Geller Jl, Louis CU, Currier MA, Racadio JM, et al. Phase 1 study of intratumoral Pexa-Vec (JX-594), an oncolytic and immunotherapeutic vaccinia virus, in pediatric cancer patients. Mol Ther. 2015;23(3):602-8.

103. Breitbach CJ, Moon A, Burke J, Hwang TH, Kirn DH. A Phase 2, Openlabel, randomized study of Pexa-Vec (JX-594) administered by intratumoral injection in patients with unresectable primary hepatocellular carcinoma. Methods Mol Biol. 2015;1317:343-57.

104. Sarker S, Athukorala A, Bowden TR, Boyle DB. Genomic characterisation of a novel avipoxvirus isolated from an endangered yellow-eyed penguin (Megadyptes antipodes). Viruses. 2021;13(2):194.

105. Stanford MM, McFadden G. Myxoma virus and oncolytic virotherapy: a new biologic weapon in the war against cancer. Expert Opin Biol Ther. 2007;7(9):1415-25.

\section{Publisher's Note}

Springer Nature remains neutral with regard to jurisdictional claims in published maps and institutional affiliations.
Ready to submit your research? Choose BMC and benefit from:

- fast, convenient online submission

- thorough peer review by experienced researchers in your field

- rapid publication on acceptance

- support for research data, including large and complex data types

- gold Open Access which fosters wider collaboration and increased citations

- maximum visibility for your research: over $100 \mathrm{M}$ website views per year

At $\mathrm{BMC}$, research is always in progress.

Learn more biomedcentral.com/submissions 